\title{
The Sin of the Gentiles: The Prohibition of Eating Blood in the Book of Jubilees
}

\author{
Todd R. Hanneken \\ St. Mary's University \\ One Camino Santa Maria, San Antonio, TX 78228, U.s.A. \\ thanneken@stmarytx.edu
}

\begin{abstract}
Jubilees exhorts Israelites to separate from Gentiles in every way. Jubilees does not simply repeat familiar arguments that Gentiles will lead Israelites to sin if they adopt their ways. Rather, Jubilees argues that merely being in the presence of Gentiles is dangerous because they are liable to a violent death at any moment for their abhorrent daily practices. At the same time, Jubilees maintains a strict standard for God's justice such that sinners must be warned of the crime and its punishment in advance. Jubilees maintains that the ancestors of all nations willingly entered into a covenant which demands eradication of entire nations for the sin of eating blood. In order to make this point Jubilees interprets Genesis 9 and other sources to indicate that all nations are bound to a covenant which demands eradication for the crime of eating meat that was not processed according to Levitical procedure.
\end{abstract}

\section{Keywords}

Jubilees - Gentiles - separation - eating blood - Genesis 9- Leviticus 17 - Aramaic Levi

Jubilees maintains a radical agenda of separation from Gentiles. ${ }^{1}$ This is evident in the discussion of specific issues such as Sabbath (2:19), nakedness (3:31),

1 The most recent discussion of anti-Gentile rhetoric in Jubilees is that of Isaac Oliver, "Forming Jewish Identity by Formulating Legislation for Gentiles," JAJ 4 (2013): 105-32, who discusses previous scholarship including Zeitlin, Rönsch, Schwarz, Werman, and Hayes. Oliver addresses the phenomenon of creating boundaries between Jews and Gentiles in 
calendar (6:35), circumcision (15:35), and intermarriage (30:7). However, Jubilees goes beyond these specific issues and mandates a radical separation from any contact with Gentiles:

Now you, my son Jacob, remember what I say and keep the commandments of your father Abraham. Separate from the nations, and do not eat with them. Do not act as they do, and do not become their companion, for their actions are something that is impure, and all their ways are defiled and something abominable and detestable. $(J u b .22: 16)^{2}$

However, Jubilees faced three problems in making this kind of exhortation. First, it was not clear to Israelites at the time of Jubilees, nor was it clear from the received sources, that all Gentiles are quite so intrinsically evil. Even among Israelites who resisted assimilation and maintained a certain contempt for Gentiles, contact with Gentiles was never so categorically prohibited. ${ }^{3}$ Received sources suggested that intermarriage could lead Israelites to idolatry, but did not categorically prohibit all contact with Gentiles. Second, since Jubilees claims that Gentile deeds are evil in themselves, not only if Israelites adopt them, there was a problem in establishing a standard of justice by which Gentiles could be judged. The Sinai covenant sets the standard for Israelite sin, including adopting certain Gentile practices, but does not establish that those practices are evil for Gentiles. Third, even if Gentiles can be categorically judged evil by a fair standard, why could a mature Israelite not co-exist with a Gentile and simply avoid the offending practices? In order to address these problems Jubilees rewrites its sources to identify a sin that is intrinsic and exclusive to Gentiles, binding on Gentiles, and so dangerous that even proximity is dangerous to Israelites. Jubilees constructs eating blood as the keystone in a system of Gentile sin which justly leads to the catastrophic destruction of all Gentiles, such that Israelites should avoid their very presence.

Jubilees and rabbinic literature through legislating observation of the Sabbath and circumcision. Oliver considers the historical context of why Jubilees opposes Jewish Hellenization and that Jubilees demonizes Gentiles. The present article explains the legal exegesis in Jubilees supporting the anti-Gentile claims observed by previous scholars.

2 Unless otherwise noted text and translations of Jubilees are from James C. VanderKam, The Book of Jubilees: A Critical Text (2 vols.; CSCO 510/511; Leuven: Peeters, 1989).

3 Resistance to Antiochus Epiphanes did not prohibit foreign alliance according to 1 Macc 8:12. Ben Sira found value in traveling among foreigners (Sir 39:4). 
First, Jubilees interprets "eating blood" as eating meat that was not processed by Levites. That is, the prohibition of eating blood serves as a summary of a complete set of laws of blood and sacrifice followed by all Levites and only Levites. Because Gentiles do not possess the books transmitted only to the Levites they are incapable of preparing acceptable meat, even if it were from a clean animal and not sacrificed to idols. It does not claim that any or all Gentiles participate in dietary or cultic practices that involve direct consumption of blood, which might have been easily refuted. This interpretation establishes a clear demarcation through an offense that is indisputably characteristic of all Gentiles and easily avoided by Israelites. Second, Jubilees interprets Gen 9 as a covenant binding on Gentiles. Thus, eating blood is an offense not only for Israelites but for all those descended from Noah. In fact, all are bound to the highest standard of culpability, including testimony, commandment, covenant, and oath. Third, Jubilees creates a new category of punishment for the violation of the Levitical slaughter regulations, namely violent eradication of all descendants.

No one who consumes blood or who sheds blood on the earth will be left. He will be left with neither descendants nor posterity living beneath heaven because they will go into sheol and will descend into the place of judgment. All of them will depart into deep darkness through a violent death. (Jub. 7:29)

The harsh rhetoric is intended to exhort Israelites to stay away from Gentiles so as to avoid their catastrophic fate.

Do not be one who eats (meat) with the blood; exert yourselves so that blood is not consumed in your presence. Cover the blood because so was I ordered to testify to you and your children together with all humanity. (Jub. 7:31)

Even the presence of a blood-eater is dangerous. Furthermore, Jubilees attaches two other sins to the system of Gentile sin centered on eating blood. Associating eating blood with idolatry builds the novel and fairly abstract argument for condemnation of all Gentiles on a long history of warnings against assimilation. Jubilees also attaches a calendar to the system of sin in order to make explicit a practical implication of avoiding all things Gentile and to provide support for the argument that the calendar is not merely a social convention but a legal obligation. 


\section{Jubilees Interprets Eating Blood as Eating Meat Not Processed by Levites}

Jubilees presents "eating blood" not as a specific practice but as representative of all the laws of handling blood described in Genesis, Leviticus, and Deuteronomy, and perhaps even a book of Noah not known to us but preserved by the Levites in the days of Jubilees (if Jub. 21:10 and 45:16 refer to actual documents). Essentially, anyone who eats meat not processed by a Levite eats blood, and anyone who eats meat processed by a Levite is safe. The point is not to expand the market of the Levites to the Gentiles, who do not have the required books, but to draw a clear line between Israelites and Gentiles.

Jubilees's sources present the prohibition of eating blood as related to the identification of blood with life. However, the sources are far from clear or consistent on what it means to eat blood or to avoid eating it. Indeed, the various articulations of the prohibition simply shuffle the words "blood," "life," "meat," "in," and "is" as if to imply a clarification, but without adding any further explanation. ${ }^{4}$

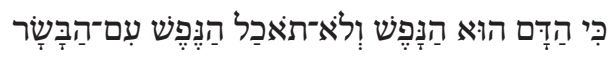

For the blood is the life; you shall not eat the life with the meat. (Deut 12:23)

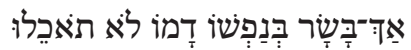

But meat with its life—its blood—you shall not eat. (Gen 9:4)

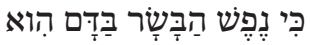

For the life of the meat is in the blood. (Lev 17:11)

For the blood is in the life. $(\operatorname{Lev} 17: 11)^{5}$

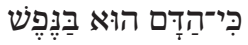

4 William K. Gilders, Blood Ritual in the Hebrew Bible: Meaning and Power (Baltimore: Johns Hopkins University Press, 2004), 16-17, 25, has appropriately warned against projecting theological explanations onto these terse words based on the scholarly imagination, or assuming that an explanation suggested in one source goes without saying in all the sources. Gilders further notes that the claim that blood is life hardly makes it obvious that life is something one would not want to eat, citing anthropological evidence of cultures that value consuming the life-force of enemies or animals.

5 Some ancient interpreters used the variations to distinguish blood from life. See Gilders, Blood Ritual, 22, 200 n. 46. 


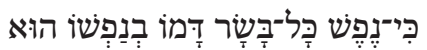

For the life of all meat—its blood is in its life. (Lev 17:14)

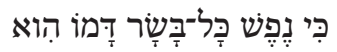

For the life of any meat is its blood. (Lev 17:14)

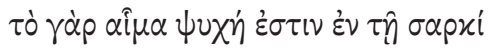

Since the blood is the life in the meat. (Aramaic Levi 55)

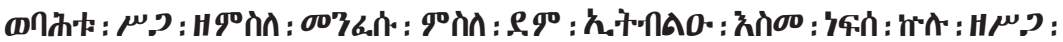 o-ìt : : $29^{\circ}$}

But you are not to eat meat that is with its life-with the blood-for the life of all that is meat is in the blood. (Jub. 6:7)

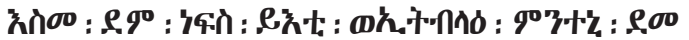

For the blood is the life; you shall not eat any blood. (Jub. 21:18)

It seems likely that some of the authors were not clear themselves on the logic or implications of the prohibition. ${ }^{7}$ From a historical-critical perspective the history of the prohibition of eating blood may be related to the Deuteronomistic prohibition of local shrines, but such a perspective was not that of Jubilees. ${ }^{8}$

6 On this particularly curious phrase see Jacob Milgrom, Leviticus 17-22: A New Translation with Introduction and Commentary (АВ 3a; New York: Doubleday, 2000), 1484.

7 The lack of a clear consensus continues in later sources independently of Jubilees, such as Philo and Josephus who present the prohibition as related to gluttony (Spec. Laws 4.122; Ant. 3.260; cf. 1.102).

8 The oldest form of the prohibition appears in 1 Sam 14, where the offense is eating on blood in the sense of slaughtering on the ground and eating in the same place, apparently perceived as an act of savagery or impiety. The solution is to designate a stone for slaughter, called an altar. However, Deuteronomy, with its program of abolishing local shrines in favor of secular slaughter, sought to reverse the sin and the solution. In 1 Sam 14 the sin was slaughtering on the ground and the solution was slaughtering on an altar. In Deut 12 the sin is slaughtering on a non-Jerusalem altar and the solution is slaughtering on the ground. As Bernard M. Levinson, Legal Revision and Religious Renewal in Ancient Israel (Cambridge: Cambridge University Press, 2008), has shown, Deuteronomy has a way of undermining legislation by appearing to uphold it. In this case, Deut 12:16 repeats the words of 1 Sam 14:32 ("blood," "eat," "on," and "ground") in a different order. Without punctuation, Deut 12:16 appears to say the same thing as 1 Sam 14:32 until one realizes that syntax requires that "on the ground" implies where the blood should go, not where it should not go: "Only the blood you will not eat on the ground you shall pour it out like water" (Deut 12:16). "On" is transposed such that the offense of eating "on" blood becomes eating blood and the pouring blood "on" the ground becomes 
The lack of clarity in the sources on the implications of the prohibition is precisely what allowed Jubilees to shape it according to its own designs.

Aramaic Levi, the relevant source closest to Jubilees in time, illustrates three interpretive foundations on which Jubilees builds and also illustrates, by contrast, two innovations in Jubilees. First, Aramaic Levi reflects the same interpretive practice exemplified by Jubilees of reconciling and synthesizing various sources related to eating blood into a unified prohibition. It is most apparent that Aramaic Levi follows Leviticus 17, particularly 17:13 for the phrase "cover it with dirt," but it also uses the phrase "eating on blood," which reflects combining the prohibition with Lev 19:26, 1 Sam 14:32-33, or Ezek 33:25. Aramaic Levi also synthesizes the Deuteronomistic and Priestly material to reconcile the spatial conflict as to whether sacrificial animals can be eaten outside the sanctuary. Whereas P requires all sacrifice-eligible animals be offered in the sanctu-

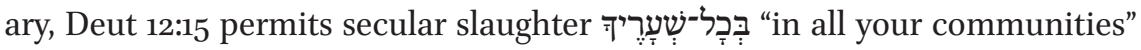
(lit. "in all your gates"). Aramaic Levi addresses this problem by imagining that the animal was sacrificed in the sanctuary by a priest and the "gates" refers to the home of the priest.

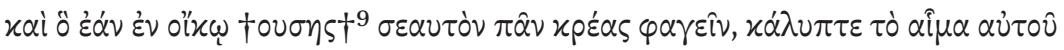

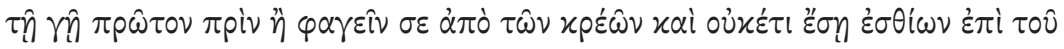

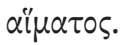

And when you are at home yourself to eat any flesh, hide its blood in the earth first before you eat from the flesh and you will no longer be eating on the blood. (Aramaic Levi 56 )

Aramaic Levi reframes the distinction between "at the temple" and "far from the temple" into a distinction between "at the temple" and "at the home of a priest." "When you are at home" echoes "in your gates" (Deuteronomy) more than "anyone hunting game" (Lev 17:13). The proposed action of hiding blood in the earth, however, paraphrases Lev 17:13, וְכְסָהּוּ בֶעָפָּר , "cover it with dirt." This synthetic approach to legal exegesis is generally characteristic of Jubilees, and on this particular point Jubilees follows Aramaic Levi in synthesizing the blood eating prohibitions as part of priestly procedure.

the solution. Subsequently in $\mathrm{P}$ and $\mathrm{H}$ the sin continues to be eating blood (no preposition) and pouring the blood on the ground is adapted slightly to covering the blood with dust.

9 Drawnel's edition uses daggers to indicate textual corruption; see Henryk Drawnel, An Aramaic Wisdom Text from Qumran: A New Interpretation of the Levi Document (JSJSup 86; Leiden: Brill, 2004). 
Second, Aramaic Levi lays the foundation for Jubilees in presenting the prohibition as a matter of priestly practice. Sources before Aramaic Levi presented the prohibition as applicable to all of Israel. Aramaic Levi places the prohibition among the instructions of Isaac to Levi on regulations particular to the Levites. As Werman has already shown, Jubilees treats "eating blood" as a comprehensive category for priestly practice. ${ }^{10}$ This can be seen most clearly in Jub. 21:6-18, where the prohibition of eating blood introduces and concludes a long list of priestly legislation including the laws of the peace offering, salt, wood, and cleansing the body and garments. The inclusio structure indicates that the prohibition of eating blood stands as metonymy for the entire set of laws of priestly procedure.

Third, Aramaic Levi provides the "genealogy" of the priestly blood regulations developed by Jubilees.

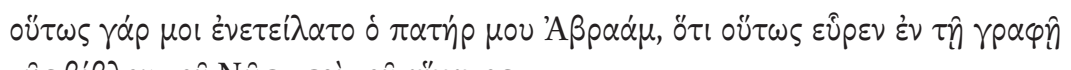

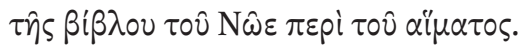

For thus my father Abraham ordered me, because thus he found in the writing of the book of Noah concerning the blood. (Aramaic Levi 57)

Jubilees does not mimic the narrative setting of Isaac's instructions to Levi, but rather develops the background suggested by Aramaic Levi by elaborating Abraham's instructions to Isaac (Jub. 21) and Noah's books (Jub. 10:14).Jubilees also explains how the works were transmitted to Abraham (Jub. 12:27; 21:10) and makes explicit the implication in Aramaic Levi that the ancient instructions are preserved by the Levites (and only the Levites) "to this day" (Jub. 45:16). ${ }^{11}$ It is also possible that Jubilees and Aramaic Levi may both refer to an actual book of Noah which is otherwise not known to us. ${ }^{12}$ Whether Jubilees refers to a literary motif from Aramaic Levi or an actual book of Noah, Jubilees

10 Cana Werman, “דין כיסוי דם ואכילתו בהלכה הכוהנית ובהלכת חכמים, Tarbiz 63 (1994): 173-84, here 174; Werman, "The Rules of Consuming and Covering the Blood in Priestly and Rabbinic Law," RevQ 16/64 (1995): 621-36, here 622; and Werman, "עיצוב מאורעות דר בסרובר המבול בספר היובלים," Tarbiz 64 (1995): 183-202, here 198-99.

11 Noah wrote books and transmitted them to Shem (Jub. 10:13-14). They ended up in the hands of Abraham (Jub. 12:27) who shared them with Isaac and Jacob (Jub. 21:10), who gave them to Levi "so that he could preserve them and renew them for his sons until today" (Jub. 45:16).

12 It is not important for the point at hand to determine whether such a fixed and widely read document existed. For that debate, see Michael E. Stone, Aryeh Amihay, and Vered Hillel, eds., Noah and His Book(s) (sBLEJL 28; Atlanta: Society of Biblical Literature, 2010). 
follows other sources for the idea that "eating blood" refers to a category of priestly procedures that originated with the most ancient priests and continues intact in the Jerusalem temple.

Comparison of Jubilees with Aramaic Levi illustrates some similarities but also two stark contrasts where Jubilees takes the implications in very different directions. First, Aramaic Levi presents refraining from eating blood as a matter of propriety and decorum with no particular punishment or emphasis of severity. This contrasts sharply with the amplification of severity developed in Jubilees and discussed below. Second, Aramaic Levi mentions Noah with no argument beyond suggesting the antiquity of the legislation. Aramaic Levi does not imply that Gentiles should also follow the laws of priestly procedure specified therein. Jubilees, however, exploits the connection to Noah in order to claim that all nations are obligated to maintain Levitical priestly procedure, as also discussed below. Before we come to the arguments that Gentiles should follow Levitical procedure and will be severely punished for failing to do so, the point at hand is that by identifying the prohibition of eating blood with standard Levitical practice Jubilees creates a clear line between Israel and the nations. Other crimes, like murder, could more easily be argued to be binding on Gentiles and would carry a severe punishment. Yet accusations such as murder would not clearly distinguish between Gentiles and Israelites-i.e., not all Gentiles commit murder, and some Israelites do. The Levitical procedures for processing meat, however, are used only by Israelites. No Gentiles have the requisite information to avoid this crime so all meat-eating Gentiles necessarily commit this offense. Israelites, at least those Israelites who avoid Gentiles, have no trouble complying with the requirement to eat meat processed by Levites. Thus, a clear divide is established: Gentiles eat blood and Israelites do not.

\section{Jubilees Interprets Genesis 9 as a Covenant Binding on Gentiles}

Jubilees is not simply arguing that Israelites should avoid Gentile meat. Rather the argument is that Israelites should avoid even the presence of Gentiles because they are all doomed to destruction. In order to make this claim, Jubilees must argue that eating blood is a sin not just for Israelites, but for Gentiles as well. Whereas the covenant at Sinai provides a clear standard by which Israelites can be punished for their sin, no such covenant clearly applies to Gentiles in sources before Jubilees. Furthermore, Jubilees follows its sources in distinguishing unintentional and intentional sins, such that sinners should have been warned of the punishment before they are fully responsible for the crime. Jubilees's determination to paint a dark picture of the fate of the 
Gentiles is matched by its determination to maintain God's perfect justice (see especially Jub. 5:13-18). Thus, Jubilees rewrites Gen 9 in order to claim that Gentiles willfully and knowingly entered into a binding covenant. This section will describe the principle received by Jubilees that sinners should be warned and persist in sinning intentionally before receiving the maximum punishment, then illustrate how Jubilees rewrites Gen 9 into a universal covenant, then describe how Jubilees applies its own standards to insist that the Gentile covenant is maximally binding.

The distinction between unintentional and intentional sins and the principle that sinners should be warned before they are liable to maximum punishment are widespread in Second Temple period literature, although the terminology varies. ${ }^{13}$ The argument that people should be warned (so that they can be fairly and harshly judged) appears especially in Ezek 3 and 33, and Neh 9. The core issue is that breaking a commandment knowingly and willfully is worse and more harshly punishable than breaking a commandment inadvertently or out of ignorance of the commandment. The Priestly source distinguishes inadvertent (בשגזה) and defiant (ביד רמה) sin (Num 15:29-30), and elsewhere זדון distinguishes the more serious defiant sin. ${ }^{14}$ That Jubilees develops the concept is clear from several passages, including the explanation of why Reuben was not held accountable for laws that had not yet been fully revealed ( $\left.J u b .33: 15^{-16}\right) \cdot{ }^{15}$ Kugel has argued that the ancient principle that sinners must be warned before they can be maximally punished stands behind several passages in Jubilees. ${ }^{16}$ He has gone as far as to argue that the key

13 For an excellent treatment of this issue see Gary A. Anderson, "The Status of the Torah Before Sinai: The Retelling of the Bible in the Damascus Document and the Book of Jubilees," DSD 1 (1994): 1-29 and Anderson, "Intentional and Unintentional Sins in the Dead Sea Scrolls," in Pomegranates and Golden Bells: Studies in Biblical, Jewish, and Near Eastern Ritual, Law, and Literature in Honor of Jacob Milgrom (ed. David P. Wright, David Noel Freedman, and Avi Hurvitz; Winona Lake, Ind.: Eisenbrauns, 1995), 49-64.

14 Anderson, "Intentional and Unintentional Sins in the Dead Sea Scrolls," 52. See also Bennie H. Reynolds III, "The Expression ביד רמה in the Hebrew Bible and the Dead Sea Scrolls and the Legacy of the Holiness School in Essene Legal Texts," JBL 132 (2013): 585-605.

15 Anderson, "The Status of the Torah Before Sinai," 19-22; Anderson, "Intentional and Unintentional Sins in the Dead Sea Scrolls," 6o-61.

16 James L. Kugel, "The Jubilees Apocalypse," DSD 1 (1994): 322-37, here 328-31. Kugel refers to Sara Japhet, The Ideology of the Book of Chronicles and Its Place in Biblical Thought (Winona Lake, Ind.: Eisenbrauns, 2009), 144-48 (pp. 183-90 in the 1989 edition) and Lawrence H. Schiffman, Sectarian Law in the Dead Sea Scrolls: Courts, Testimony, and the Penal Code (BJs 33; Chico, Calif.: Scholars Press, 1983), 89-98. 
concept in Jubilees "testify/testimony" should be translated "warn/warning."17 "Testimony" captures nicely the range of uses that תעודה carries inJubilees, but the point stands that "warning" is a key function of "testimony" in Jubilees. In fact, testimony is only one of the related means to reinforce the seriousness of a sin and the culpability of the sinner, all of which Jubilees applies to the prohibition of eating blood.

Jubilees establishes that all nations were duly warned and remain culpable by combining the prohibition in Gen 9:4 with the covenant with all living creatures later in the chapter. In Genesis the covenant is unconditional and applies only to not flooding the earth again. However, it is addressed to Noah and

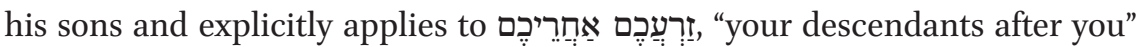
(Gen 9:9), such that it is binding on all nations. From a modern perspective the qualified meat permission and the covenant not to flood the earth again are discrete units placed next to each other by a redactor who developed no particular relationship. Jubilees reads the prohibition as a condition of the covenant. The effect, according to Jubilees, is that all the descendants of Noah are fully responsible for the prohibition of eating blood.

No source before Jubilees incorporates the qualified permission to eat meat as a condition of the structurally distinct covenant that follows in the same chapter. ${ }^{18}$ Aramaic Levi develops the idea that Noah received commandments about blood other than "don't eat it," but makes no suggestion that priestly procedure is a universally binding covenant. Aramaic Levi develops Noah as an arch-priest, but Jubilees develops another side of Noah, as the father and warner of all nations. Enochic writings may precede Jubilees for the idea that other nations have been warned by their ancestor, but they do not develop Noah as the warner, Gen 9 as the covenant, or eating blood as the paradigmatic

17 James L. Kugel, A Walk through Jubilees: Studies in the Book of Jubilees and the World of its Creation (JSJSup 156; Leiden: Brill, 2012), 3. See also the extended discussion of the importance and meaning of "testimony" in Michael Segal, The Book of Jubilees: Rewritten Bible, Redaction, Ideology and Theology (JSJSup 117; Leiden: Brill, 2007), 282-316.

18 Readers familiar with the concept of Noachide laws in rabbinic literature may take this for granted as explicit or implicit in Gen 9, but the idea of a Noachide covenant is not attested before Jubilees. Markus Bockmuehl, "The Noachide Commandments and New Testament Ethics: With Special Reference to Acts 15 and Pauline Halakhah," RB 102 (1995): 72-101, here 88, asserts that Jubilees is the only pre-rabbinic source to reflect the idea of Noachide laws. Werman, "דין כיסוי דם ואכילתו," 173-84, however, argues that the rabbinic view was already established before Jubilees polemicizes against it; cf. the revised and translated argument in “The Rules of Consuming and Covering Blood," 621-36. 
Gentile sin. $\cdot{ }^{19}$ Jubilees draws from a variety of contemporary ideas but develops a new argument for the covenantal obligations of all Gentiles.

Jubilees has its own distinctive language for emphasizing maximum legal culpability. ${ }^{20}$ Jubilees received the ideas that sinners should be warned and that covenants can be eternally binding and develops a four-fold rhetoric for maximally binding obligations, namely: testimony (especially written testimony), commandment, covenant, and oath. One of the senses of "testimony" in Jubilees is a narrative that illustrates a legal case establishing the justice of God's resolution and precedent for a binding law. In the case of eating blood, the story of the pre-flood cannibalism suggests the justice of the punishment and the precedent for the prohibition..$^{21}$ As Jubilees presents it, Noah and his

19 It is difficult to be sure which texts and traditions predate Jubilees and which may have taken shape later, perhaps even under the influence of Jubilees. The Book of the Watchers, essentially as we know it, was a source for Jubilees (Segal, The Book of Jubilees, 109-16). The Book of the Watchers portrays Enoch as a scribe who plays a key role in a legal proceeding (1 En. 12-16). Jubilees presents this function as the role of testifying, and expands it from testifying to the watchers (Jub. 4:22) to testifying to all humanity (Jub. 4:18-19). At least the general point that Enoch testified to humans, namely his sons (from whom are descended Noah and all nations), can be found mentioned in the framing material of the Book of Dreams and Apocalypse of Weeks (1 En. 83:1; 85:1; 91:1-3; 93:2). It is far from clear that the point is that the Gentiles were given laws and warned. The brief mention of Enoch's instructions to his sons may have more to do with explaining the transmission of the visions. From a literary perspective the "sons" in these passages seem to evoke the actual audience and do not refer to wicked Gentiles. One might also consider 1 En. 81:6, but here the relationship of the Ethiopic Astronomical Book to the sources available to Jubilees is even more complicated. See George W. E. Nickelsburg and James C. VanderKam, 1 Enoch 2: A Commentary on the Book of 1 Enoch, Chapters 37-82 (Hermeneia; Minneapolis: Fortress, 2011), 357, 398-99. Also relevant to the idea of Noachide laws is the mention in the Apocalypse of Weeks that "a law will be made for sinners" ( 1 En. 93:4). The idea that Enoch warned the Gentiles of judgment for their wickedness is most clearly evident in the Epistle of Enoch, which took shape later than Jubilees, although one could easily imagine that the ideas and explications of earlier sources were available by the time of Jubilees. "Wickedness" in the Epistle of Enoch seems to be a rather robust and unmistakable evil, not the curious construction of "eating blood" as eating meat outside the Levitical system.

This rhetorical arsenal was first described by Leora Ravid, "המינוח המיוחד של לוחות השמים בספר היובלים, Tarbiz 68 (1999):463-71. Kugel, “On the Interpolations in the Book of Jubilees," RevQ 24/94 (2009): 215-72 has drawn from the distinctiveness of the elevated rhetoric to suggest a different author, or interpolator, was responsible for those passages. See also, Kugel, Walk through Jubilees, 227-96.

21 The identification of the pre-flood cannibalism with eating blood is suggested but less than perfectly clear. Jub. 5:2 indicates that "they began to devour one another." The 
sons saw the sin and punishment, so they already had reason to believe that the sin was serious. That is, the flood story testifies to the importance of not eating blood. Similarly, Noah testifies to all humanity the consequences of eating blood and related violations ( $J u b .7: 31)$. The second rhetorical device is to give God's blessing of qualified permission to eat meat the status of a commandment. Jubilees replaces the blessing of "may you be fruitful and multiply" (Gen 9:1) with a commandment to become a blessing and to be fruitful and multiply (Jub. 6:5). Jubilees applies the explicit language of commandment to the restriction in 6:13-14 and 21:5-6. The rhetorical elevation of the imperative to a commandment is carried further by the third rhetorical device, reframing the entire passage as stipulations of a covenant. Genesis 9 does use the language of covenant, but only later in the following passage, where it is an unconditional promise by God not to flood the earth again, with no mention of blood prohibitions (Gen 9:8-17). Jubilees has the covenant begin earlier (Jub. 6:4), such that the blessings and qualifications become stipulations of the covenant with all the descendants of Noah. ${ }^{22}$ Fourth, the ultimate seal of culpability is an oath. "Oaths" are a major concept in Jubilees and function here to establish that Noah's sons accepted the testimony, commandment, and covenant, along with its punishment. The language of testimony, commandment, covenant, and oath appears frequently in the relevant chapters, particularly the following passage:

Noah and his sons swore an oath not to consume any blood that was in any animate being. During this month he made a covenant before the Lord God forever throughout all the history of the earth. For this reason he told you, too, to make a covenant-accompanied by an oath-with the Israelites during this month on the mountain and to sprinkle blood on them because of all the words of the covenant which the Lord was making with them for all times. This testimony has been written regarding

identification of the life with the blood is clear in the sources but not Jub. 5:2. Later, Noah discusses at length eating blood in an exhortation based on the lesson of the flood, but eating blood is not one of the three explicit causes of the flood ( Jub. 7:20-33). In Jubilees's source the Book of the Watchers, the pre-flood cannibals "began ... to devour one another's flesh and they drank the blood" ( 1 En. 7:5, 4Q202 [En ${ }^{\mathrm{b}}$ ar] 1 ii 25a).Jubilees parallels the first part but not the second. Also, the Aramaic fragment makes clear that the verb is "drank" not "ate." Although it is odd that Jubilees would not mention eating blood explicitly in $5: 2$ the association between cannibalism and eating blood is clear enough for the point at hand.

22 See Werman, "דין כיסוי דם ואכילתו," 174; "The Rules of Consuming and Covering Blood," 622; and "דר המבול," 191-94. 
you to keep it for all times so that you may not at any time eat any blood of animals or birds throughout all the days of the earth. (As for) the person who has eaten the blood of an animal, of cattle, or of birds during all the days of the earth - he and his descendants will be uprooted from the earth. Now you command the Israelites not to eat any blood so that their name and their descendants may continue to exist before the Lord our God for all time. This law has no temporal limits because it is forever. (Jub. 6:10-14)

This passage illustrates the seriousness of the commandment in that it is maximally binding, based on all the means that Jubilees uses to establish culpability and justice of punishment. Finally, Jubilees concludes the passage with its emphatic formula for eternal law. The Gentile covenant is maximally binding and eternal. It makes no difference that the Gentiles no longer possess Noah's books which might give them a chance of compliance.

Jubilees holds Gentiles accountable to judgment because their ancestors willfully accepted a covenant bearing specific penalties for a specific crime, and then committed that very crime. This might have sufficed if the purpose were to exhort Gentiles to repentance or to promise to the oppressed that the oppressor will be judged. However, in order to exhort Israelites to avoid even being near Gentiles and their catastrophic fate it was necessary to amplify the severity of the punishment beyond the penalty provided in the sources for eating blood or any crime.

\section{3} Jubilees Amplifies the Seriousness of the Sin and Its Punishment

The purpose of presenting the prohibition of eating blood as binding on Gentiles is not to exhort Gentiles to change their dietary or butchering habits (cf. Acts 15:20). Rather, the argument is that Israelites should separate from Gentiles in order to avoid the catastrophic destruction to which they are justly sentenced. However, the sources available generally indicate an instruction with no specific punishment, or in the case of Leviticus the punishment of excision (כרת) of the individual from his or her nation. ${ }^{23}$ Jubilees amplifies the punishment in two ways. First, Jubilees creates a new interpretation of

23 One might get the sense from Aramaic Levi 56 that covering blood before eating is a matter of decorum or table manners for the priestly class. In 1 Sam 14:33, eating on blood is described as a sin against God and acting treacherously, which certainly can be dangerous for soldiers at war, but neither Saul nor God punish anyone for the offense. Indeed, the 
excision that applies to entire nations. Second, Jubilees rewrites Gen 9 to transform murder from a parallel prohibition to a consequence of eating blood.

Jubilees nationalizes the penalty of excision for eating blood. Leviticus provides the punishment of excision for eating blood, most directly the excision

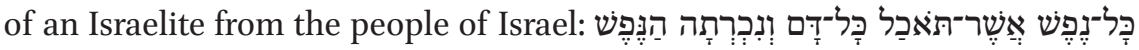
"every life (person) that eats any blood, that life will be cut off from its people" (Lev 7:27; see also Lev 17:10, 14). It would be simple enough to interpret the punishment to mean that any Gentile would be excised from his or her nation. However, Jubilees is concerned not with individual crime and punishment but with the fate of nations, so an individual being cut off from his or her people does not suffice. The punishment of excision for eating blood, like all punishments of excision in the Torah, applies to individuals. Jubilees extends the punishment to descendants (lit. seed), which in the context of the origin of the nations extends the punishment to nations. ${ }^{24}$

(As for) the person who has eaten the blood of an animal, of cattle, or of birds during all the days of the earth-he and his descendants will be uprooted from the earth. (Jub. 6:12)

Ethiopic wLD "eradicate, uproot" translates כרת "cut off."25 The punishment of excision never applies to descendants in the Torah. Support for amplifying

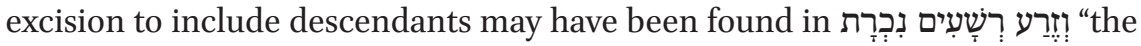
seed of the wicked is cut off" (Ps 37:28), although no specific offense calls for such a punishment there or elsewhere. ${ }^{26}$ Rather, the justification for nationalization of the punishment builds on Gen 9:9, which extends the covenant

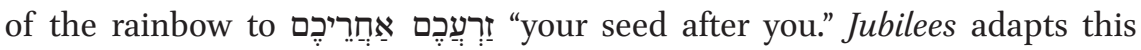
multi-generational language from meaning that the law applies to all genera-

offense is ameliorated merely by ceasing to commit it. Eating blood itself bears no explicit punishment in Deut 12 or Gen 9.

24 Werman, "דר המבול,", 196.

25 Milgrom, Leviticus 17-22, 1503. For a discussion of the meaning of "excision" see Jacob Milgrom, Leviticus 1-16: A New Translation with Introduction and Commentary (A в 3; New York: Doubleday, 1991), 457-60.

26 Negative forms (may they not be cut off) are found in 1 Sam 24:22 and Isa 48:19. Werman, "דר המבול," 196, links the punishment to the punishment of the flood, which implicitly killed the seed of the sinners. The difference is that according to Jubilees everyone killed in the flood was personally culpable ( $J u b .5: 2-3$ ), and depriving them of yet unborn descendants differs from killing them many generations later. However, it is tempting to compare the flood itself to the otherwise unparalleled eradication of nations for eating blood. See note 22 above. 
tions to meaning that the punishment applies to all generations. If the punishment applies to all descendants, and the sons of Noah all violated the law, then all nations are subject to excision simply because the punishment for the sin of their ancestor includes all descendants. In this way, Jubilees creates a category of punishment harsher than most sources, which would limit intergenerational punishment to only a few generations or deny it entirely. ${ }^{27}$ This unprecedented harshness was certainly not directed at Israelites. Jubilees follows Leviticus in allowing atonement for Israelites, but explicitly denies it to other nations. ${ }^{28}$

As unpleasant as excision may be, it is a distinctly lower category of punishment than capital punishment, the catastrophic fate which Jubilees exhorts Israelites to avoid. ${ }^{29}$ One might imagine that the newly created punishment of national excision simply means that Gentiles will be cut off from the land or people of Israel and go live a separate existence. In Jub. 6:12 (quoted above) the excision could be from either the land or the earth (Ethiopic $\mathbf{9 0}$..$C$. can mean the land of Israel or all the earth). ${ }^{30}$ Jubilees 7:29 favors the harsher interpretation, since "beneath heaven" includes lands besides Israel.

No one who consumes blood or who sheds blood on the earth will be left. He will be left with neither descendants nor posterity living beneath heaven because they will go into sheol and will descend into the place of judgment. All of them will depart into deep darkness through a violent death. $(\text { Jub. } 7: 29)^{31}$

27 Exod 20:5-6; Jer 31:29-31; Ezek 18:1-4; Deut 7:9-10; Targum Onqelos to Exod 20:5. For discussion see Levinson, Legal Revision and Religious Renewal.

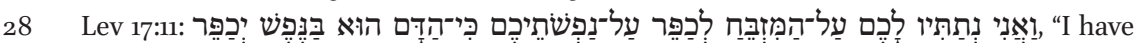
given you [the blood] for the altar so as to atone for your lives, for the blood which is in the life will atone"; cf. Jub. 5:17: "Regarding the Israelites it has been written and ordained: 'If they turn to him in the right way, he will forgive all their wickedness and will pardon all their sins.'"

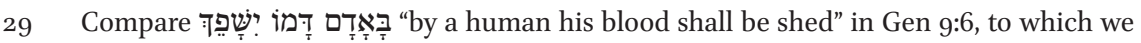
shall return.

30 Betsy Halpern-Amaru, Rewriting the Bible: Land and Covenant in Post-Biblical Jewish Literature (Valley Forge: Trinity Press International, 1994), 28, 140-41 n. 19.

31 The harsh rhetoric does not mean that the author called for militant activism or expected the audience to slaughter Gentiles; indeed the general message of the book is "separate from Gentiles because they have no future in God's long-term plan." On the absence of militancy in the book of Jubilees see Todd R. Hanneken, The Subversion of the Apocalypses in the Book of Jubilees (SBLEJL 34; Atlanta: Society of Biblical Literature, 2012), 111-17. 
However, the penalty of "violent death" goes well beyond the punishment of excision supplied by Leviticus, even after it is adapted to apply to nations. In order to establish the penalty of violent death Jubilees must make use of additional sources, in this case by further rewriting of Gen 9. Jubilees rewrites Gen 9 such that violent death is not a parallel prohibition but the consequence of eating blood. Although Gen 9:4 gives no punishment for violating the commandment not to eat blood, Jubilees melds the prohibitions of eating blood and murder in Gen 9 in order to equate eating blood with murder in severity and punishment by human means. In Gen 9 eating blood and shedding human blood are juxtaposed but distinct commandments. Jubilees equates eating blood with murder on several occasions, most explicitly in the reworking of Gen 9:4-5 in Jub. 6:7.32 This passage well illustrates the subtlety of innovationone might say slight-of-hand-in Jubilees's use of sources. Barely a word is changed outright, but the change in meaning is radical. Consider Jubilees and its sources:

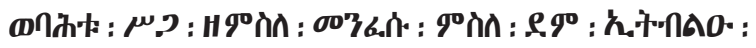

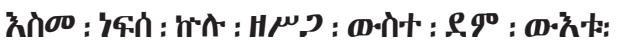

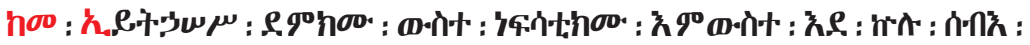

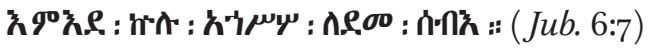

But you are not to eat animate beings with their spirit — with the blood(because the vital force of all animate beings is in the blood)

so that your blood with your vital forces may not be required from the hand of any man.

From the hand of each one I will require the blood of man. (Jub. 6:7, VanderKam's translation)

Only flesh that is with its spirit with the blood you are not to eat because the life of all that is flesh it is in the blood lest your blood in your life be required by the hand of all people from the hand of all people I will require the blood of people. (Jub. 6:7, very literal translation)

"אך בשר בנפשו בדם לא תאכלו

כי נפש כל בשר בדם הוא בנפוא

$3^{2} \quad J u b .7: 32$ and 21:18-19 are also good examples. 
ולא 33ידרש דמכם בנפשכם מיד כל אדם מיד כל אדם אדרש דם אדם במנפם מיד (unattested reconstruction of Hebrew Jubilees)

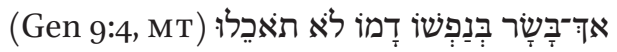

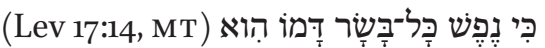

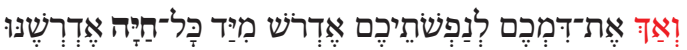

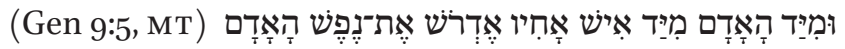

A number of curious minor variants remind us not to assume that the Masoretic text lay before the author of Jubilees. The important point here is that with a single particle Jubilees changed two laws into one law specifying violent death as the consequence of eating blood. Genesis 9:5 opens with ואך "only, also" mirroring the beginning of Gen 9:4 and indicating a structure of two parallel and independent restrictions on the preceding permission to slaughter. ${ }^{34}$ The fundamental change in Jubilees is to replace ואץ "lest." ולא "lenly" withe slight-of-hand is masked with the distraction of inserting the explanation from Lev 17:14. Upon returning to Genesis a small connecting word is changed. ${ }^{36}$ Other than word order (which cannot be reliably reconstructed from the Ethiopic anyway) the only other substantial change is from מיד כל חיה "from

33 Strict adherence to the Ethiopic (Glt subjunctive) would call for reconstructing a reciprocal form, "will be collectively required." The sentence would also make sense with the same form as Gen 9:5 (אדרש) if it seems more likely that the author adhered to the base and a transmitter adjusted the syntax; cf. Thomas Oden Lambdin, Introduction to Classical Ethiopic (Ge'ez) (HSS 24; Missoula, Mont.: Scholars, 1978), 101, 205, 446.

34 The Samaritan Pentateuch lacks ואץ; see Jacques T. A. G. M. van Ruiten, Primaeval History Interpreted: The Rewriting of Genesis 1-11 in the Book of Jubilees (JSJSup 66; Leiden: Brill, 200o), 235. There is a good frequency of cases when the text used by Jubilees seems to have resembled the Samaritan Pentateuch more than the Masoretic Text; see James C. VanderKam, Textual and Historical Studies in the Book of Jubilees (Missoula, Mont.: Scholars, 1977), 136. It may be the case that we have here an addition rather than a substitution, and that a slight difficulty in the text prompted the innovation in Jubilees. However, the basic point remains. The logic of the Samaritan is the same as the Masoretic Text, with the second clause depending on the same אך as the first clause. Jubilees's addition of "lest" is significant and purposeful in the larger plan of Jubilees, not explicable from any attested text of Genesis.

35 Another example of Jubilees changing the meaning with a subtle change of particle is described by Anderson, "The Status of the Torah Before Sinai," 27-28.

36 It is possible that the ולא ("for the blood is the life") is followed by ולא.Jubilees 7:32 repeats the same basic formula. 
the hand of every living thing" to מיד כל אדם "from the hand of every person," which would sound perfectly concordant because the next phrase in the same verse is none other than מיד כל אדם "from the hand of every person." The change in meaning resulting from the change in particle is substantial. Whereas Genesis demanded the death penalty for human murder, it offered no penalty for eating animal blood. In Jubilees, human murder goes from an independent offense to the consequence of eating blood. The consequence is then explained as just punishment ordained by God. ${ }^{37}$ Thus "eating blood" becomes

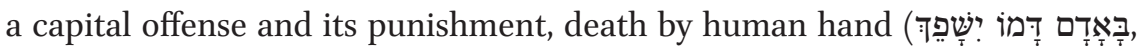
Gen 9:6), is the same as the punishment for murder.

Jubilees does not stand alone in the view that Gentiles could and would be judged by God for their wickedness. For example, Enochic literature around the time of Jubilees indicates that Gentiles were warned by their ancestor and will be judged by God for their wickedness. ${ }^{38}$ The system of Gentile sin and punishment constructed by Jubilees differs substantially, however. There is no sympathy that some Gentiles might not be wicked or that one day some Gentiles might be made righteous. The sin of not following Levitical procedure is intrinsic to all Gentiles. Furthermore, Gentiles eating blood is not an offense against Israelites. Jubilees is not promising justice to the oppressed, but exhorting radical separation by asserting that Gentiles and any attached to them have no future. Jubilees is not following a visceral path to the assertion of a just God in the face of injustice, but constructing an intricate legal system to mandate a radical agenda of social separation. Certain innovations in Jubilees, such as the idea of a Noachide covenant, would reverberate through later sources, but never with the same purpose and detailed reasoning as Jubilees. The claim that all Gentiles (in as much as all eat non-Levitical meat and are descended from the sons of Noah) are bound by an eternal covenant (and testimony, commandment, and oath) and will be punished with violent eradication (based on nationalizing excision across generations, and adapting violent death from a prohibition to a punishment) creates a clear message for the Israelite audience: any perceived benefit of associating with Gentiles will be short-lived and will end with sharing their complete and violent annihilation.

37 A similar observation was made by Werman, "דין כיסוי דם ואכילתו," 174; cf. "Consuming and Covering Blood," 622.

38 See note 19 above. 
Accusing Gentiles of not following Levitical practice and thus violating the prohibition of eating blood merely laid the foundation for the main objective of Jubilees, to legislate radical separation from all Gentiles. It was inevitable that Jubilees would include in its sophisticated construction of Gentile sin the simplest argument from the broadly received sources for separation from Gentiles. The Deuteronomists in particular make the point that intermarriage with idolaters threatens to lead Israelites into idolatry. Jubilees links eating blood to idolatry as part of the system of Gentile sin, but Jubilees goes far beyond the received arguments. Jubilees calls for separation that goes beyond the prohibition of intermarriage to the prohibition of even being in the presence of Gentiles (7:31).Jubilees also eliminates the possible loophole that Gentiles who abandon idolatry might be acceptable or that coexistence might be possible in capacities that do not involve idolatry. The argument in Jubilees is not the argument found in rabbinic literature that Gentiles are compulsive idolaters and care is required to maintain separation from idolatry if one cannot maintain separation from Gentiles. ${ }^{39}$ The argument in Jubilees is also different from the argument advanced by Maimonides, and followed by Grintz and Milgrom, that chthonic rituals involve eating blood so the prohibition of eating blood is a corollary of the prohibition of idolatry. ${ }^{40}$ As Jubilees presents it, especially in

39 See Sacha Stern, "Compulsive Libationers: Non-Jews and Wine in Early Rabbinic Sources," JJS 64 (2013): 19-44.

40 Maimonides explained the prohibition of eating on blood as related to the prohibition of idolatry by asserting that idolaters eat on blood as part of their rituals. Jehoshua M. Grintz, "'Do Not Eat On the Blood': Reconsiderations in Setting and Dating of the Priestly Code," ASTI 8 (1970-1971): 78-105, here 79-83 (first published in 1966 in Hebrew), sought support for this interpretation by arguing that the ancient Greeks distinguished sacrifices for underworld beings from sacrifices for Olympian gods (see $\mathrm{Od}$. 11.23-37). Thus, "eating on the blood" referred to a ritual of offering blood as food to underworld spirits. Milgrom, Leviticus 17-22, 1490-93, supported this line of thinking with some caveats. It should be noted that this explanation does not serve well to explain most of the related passages or the historical development of the prohibition. 1 Samuel 14 suggests a sin of hunger-driven savagery or perhaps failure to offer animals to God, but not hunger-driven divination. Furthermore, prohibiting living humans from eating blood is the opposite of prohibiting them from feeding it to underworld spirits. Indeed, pouring blood on the ground is the solution in D and P, not the sin. Leviticus 19:26 might work with the suggestion that eating on blood was a divinatory practice, but Grintz's claim that the idiom means the same thing in all contexts does not work. Another forced argument to link eating on blood to divination appears in Pamela Tamarkin Reis, "Eating the Blood: Saul and the Witch of 
the rewriting of the covenant in Gen 9, the opposite is the case. Eating blood is the core sin which is intrinsic to Gentiles, binding on Gentiles, and justifies the doom of Gentiles, from whom Israelites must separate to avoid their doom. Idolatry is a part of the system but is logically subordinate because the sources are not clear that Gentiles are obligated on pain of death to avoid idolatry. ${ }^{41}$ This section will show three ways in which Jubilees links idolatry to eating blood as the paradigmatic Gentile sin.

The first and simplest way Jubilees develops the link is simply by juxtaposing and interchanging the offenses and punishments. For example, consider the juxtaposition in Abraham's instructions to Isaac. Abraham opens by explaining himself as an idol hater then gives commandments about idolatry and eating blood.

Now you, my son, keep his commandments, ordinances, and verdicts. Do not pursue unclean things, statues, or molten images. Do not eat any blood of an animal, cattle, or of any bird that flies in the sky. (Jub. 21:5-6)

Without context from the rest of the book, this might be thought of as a simple non-sequitur in a list of unrelated commandments. However, the relationship that emerges is that these are not only two very important commandments, but that they fundamentally distinguish the righteous from the wicked, the chosen line from the nations. It might be argued that the link by association already existed in Jubilees's sources, especially if one does not distinguish eating blood from eating on blood. ${ }^{42}$ The closest juxtapositions between idolatry and eating on blood appear in Lev 19:26 and Ezek 33:25. It is certainly possible that the author of Jubilees or any other reader could have read Lev 19 to equate eating on blood with divination, but divination is not the issue in Jubilees. Similarly, Ezekiel might have supported the author of Jubilees in thinking that eating (on) blood is as bad as idolatry and murder, but the juxtaposition of three offenses does not equate eating blood with idolatry any more than murder. Whatever sources may or may not have influenced the author's thought, the arguments articulated in Jubilees, particularly the following two points, go beyond the juxtaposition found in any of the sources.

Endor," JSOT 73 (1997): 3-23, here 7, 17. Even if Lev 19:26 understands eating on blood as related to divination, such an implication is not picked up in Jubilees.

41 Jubilees is clear that worshiping the God of Israel in Jerusalem is not an option for Gentiles. Even if idolatry itself is not commanded for Gentiles, God does want Gentiles led away from Israelite worship (Jub. 15:31). See Hanneken, Subversion of the Apocalypses, 183-87. 
The second way Jubilees links eating blood and idolatry is to develop an etiology of idolatry intertwined with the rejection of Noah's prohibition of eating blood. Genesis never offers an etiology of idolatry. Noah's sacrifice is clearly not idolatrous since it is pleasing to the Lord (Gen 6:3). "Household gods" first appear in the Jacob story as belonging to Laban, where they are mentioned with no explanation of origin (Gen 31:19). Modern interpreters would link the lack of explanation to the relatively late development of radical monotheism, but ancient interpreters saw this as a gap to fill. It may seem inevitable with retrospect that the origin of idolatry would be placed between Noah and Abraham, but Genesis gives no indication of the origin of idolatry or even that Abraham was an idol hater, as becomes a dominant identification in Jubilees and other ancient traditions. ${ }^{43}$ One clue appears in the book of Joshua: "And Joshua said to all the people, 'Thus says the LORD, the God of Israel: Long ago your ancestors-Terah and his sons Abraham and Nahor-lived beyond the Euphrates and served other gods" "(Josh 24:2). Between Noah and Abraham Genesis offers a story of a tower and a table of nations. Jubilees has relatively little to say about the tower, but greatly expands the table of nations to develop a theology of the Gentiles and why they should be avoided. This is true in many ways, including territory, slavery, and empire, but also for the point at hand: eating blood and idolatry appear as defining Gentile characteristics after the death of Noah. Here we find Jubilees's etiology of Gentiles, which entails an etiology of eating blood and idolatry:

${ }^{2}$ During this jubilee Noah's children began to fight one another, to take captives, and to kill one another; to shed human blood on the earth, to consume blood; to build fortified cities, walls, and towers; men to elevate themselves over peoples, to set up the first kingdoms; to go to warpeople against people, nations against nations, city against city; and everyone to do evil, to acquire weapons, and to teach warfare to their sons. City began to capture city and to sell male and female slaves. Ur, Kesed's son, built the city of Ara of the Chaldeans. He named it after himself and his father. They made molten images for themselves. Each one would worship the idol which he had made as his own molten image. They began to make statues, images, and unclean things; the spirits of the savage ones were helping and misleading (them) so that they would commit sins, impurities, and transgression. Prince Mastema was exerting his power in effecting all these actions and, by means of the spirits, he was 
sending to those who were placed under his control (the ability) to commit every (kind of) error and sin and every (kind of) transgression; to corrupt, to destroy, and to shed blood on the earth. (Jub. 11:2-5)

This etiology of idolatry provides not only a chronological framework for when idolatry developed, but an explanation. Prince Mastema and the "spirits of the savage ones," who are the demons that originated as the spirits of the giants, cause idolatry along with the other paradigmatic Gentile offenses. Some scholars have characterized Mastema as a force of cosmic evil or the dark side of created dualism. ${ }^{44}$ However, demons and Mastema (like idols) do not even appear in Jubilees until after the division of the nations because they are fundamentally a Gentile problem. ${ }^{45}$ Whereas eating blood appears in a long list of sins in the above etiology of Gentiles, the demonic nature of eating blood is more direct in another passage in which Noah anticipates that his sons will follow demons to two cardinal offenses: "For I myself see that the demons have begun to lead you and your children astray; and now I fear regarding you that after I have died you will shed human blood on the earth and ... consume the blood" (Jub. 7:27-28). Thus, Jubilees develops the association between eating blood and idolatry, not that idolatry involves eating blood or that eating blood is itself idolatrous, but that both are parallel offenses in a system of Gentile sin with the same demonic origin.

The third way Jubilees links eating blood to idolatry as paradigmatic Gentile offenses is in the development of Abraham as the original counter-Gentile. Jubilees presents the period from Noah to Abraham as a sequence of errors that characterize Gentiles, the conquering of which characterizes Abraham. First, Gentiles are associated with illicit teaching. Jubilees borrows this idea from the Book of the Watchers but moves it to after the division of the nations and narrows it to astrology in particular ( Jub. 8:3). ${ }^{46}$ This astrology makes its way to Ur of the Chaldeans $(J u b .11: 3,8)$. There, this Gentile error is refuted and rejected by Abraham, leading him to choose the one true God (Jub. 12:16-19). Second, this false teaching is closely associated with idolatry, which develops at the same

44 See especially Segal, The Book of Jubilees, 263-69.

45 Todd R. Hanneken, "Angels and Demons in the Book of Jubilees and Contemporary Apocalypses," Hen 28.2 (2006): 11-25, here 17-18; Hanneken, Subversion of the Apocalypses, 63-64, 77 .

46 Todd R. Hanneken, "The Watchers in Rewritten Scripture: The Use of the Book of the Watchers in Jubilees," in Fallen Angels Traditions: Second Temple Developments and Reception History (ed. A. K. Harkins, K. Coblentz Bautch, and J. C. Endres; СвQмS 53; Washington, D.C.: Catholic Biblical Association of America, 2014), 25-68. 
time (Jub. 11:4). Similarly, Abraham refutes and rejects this error (Jub. 11:16; 12:2, 12). Third, idolatry is closely related to dominion by demons and Mastema (Jub. 11:5), which leads to other torments. Abraham defeats the demons and Mastema on at least two occasions. First, Abraham thwarts Mastema's ravens by inventing a plow which covers the seed (Jub. 11:23-24). Later, Abraham puts Mastema to shame by passing a test provoked by Mastema-the willingness to sacrifice Isaac ( Jub. 18:12). All of these Gentile errors and Abrahamic rejections amount to more than a list of bad ideas and good ideas. There is a Gentile system consisting of an interconnected web of false wisdom, idolatry, and demonic persecution, the entire system of which is escaped by Abraham's system of righteousness. Jubilees places "eating blood" as the keystone in the Gentile system of error and the Abrahamic solution. "Eating blood" appears repeatedly in lists of Gentile error ( Jub. 7:28; 11:2), and in Abraham's teaching about the importance and means of separating from Gentiles. After Noah, the chief opponent of eating blood in Jubilees is none other than Abraham. ${ }^{47}$ This third point best illustrates the purpose of Jubilees to exhort Israelites, not to avoid eating blood, but to follow the example of their ancestor Abraham in separating from Gentiles.

By incorporating idolatry into the system of Gentile sin, Jubilees builds on a well-established foundation of calling for Israelite separation from idolaters. What may be surprising is that the argument for separation from idolatry is not Jubilees's main argument for separation from Gentiles. Certainly separating from idolatry remains an integral component, but the focus on the constructed Gentile sin of eating blood offers two advantages. First, the avoidance of idolatry allows for gray areas of Gentiles who abandon idolatry, or the possibility of coexistence in social arenas that do not involve idolatry. The accusation of not following Levitical procedure is more intrinsic, particularly as Jubilees adds that even being descended from a blood-eater merits punishment and that even being in the presence of a blood-eater is unacceptable for Israelites. Second, although idolatry is clearly forbidden for Israelites, it is not so clearly forbidden for Gentiles. The concern to speak of all Gentiles led Jubilees to the narratives from primordial times that include the ancestors of all nations. Eating blood was more easily interpreted as a universal obligation, based on Gen 9, than any

Note that the construction of Abraham as the arch-separator may explain why Jubilees diverges from Aramaic Levi in placing the exhortation not to eat blood on the lips of Abraham rather than Isaac. Whereas the point in Aramaic Levi is priestly practice, the primary point in Jubilees is separation from Gentiles, so the counter-Gentile Abraham is the natural teacher against the Gentile system of error, including idolatry and eating blood (Jub. 21:5-6). 
prohibition or ridicule of idolatry for Gentiles. However, attaching idolatry to the system of Gentile sin had the advantage of immediate and strong negative connotations. The argument that Israelites should avoid the presence of Gentiles because they all will be destroyed for the sin of not following Levitical procedure, even though carefully constructed in Jubilees, may have sounded too abstract or unfamiliar. By linking eating blood and idolatry Jubilees gains the advantages of each. The justice of the judgment holds up to scrutiny, and the well-established negative connotations of idolatry carry over to eating blood. Eating blood and idolatry belong together as equally bad, equally traceable to demonic origins, and equally rejected by the arch-separator Abraham.

\section{Jubilees Attaches the Calendar to the System of Unforgivable Gentile Sins}

The basic system of Gentile sin warranting Gentile eradication and mandating radical Israelite separation has already been established. However, Jubilees could not resist adding one additional issue, the calendar, to the system of unforgivable Gentile sin. The presumed reasons for this are two-fold. First, the system of Gentile sin focusing on their diet and inevitable fate may have been too abstract, and Jubilees was deeply concerned about the very practical issue of the festival calendar. ${ }^{48}$ We already saw that Jubilees attached the established point about idolatry to the system of Gentile sin, but the acceptability of idolatry seems not to have been as hotly debated in the circles close toJubilees as the issue of the calendar. Second, the argument easily fell into place givenJubilees's efforts to ground the calendar as a legal obligation based on its rewriting of the flood and Noah chapters in Genesis. Since Noah and sons participated in the flood they should have known the proper calendar. The Gentile rejection of God's calendar is consequently woven into the system of fundamental sin

48 The author viewed the festival calendar as synchronized with a heavenly festival calendar, so the people of Jerusalem had to choose between synchronizing with their Gentile neighbors and synchronizing with the angels. The consequence of choosing incorrectly was that celebrating festivals on the wrong day would be worse than not celebrating them at all; Israel would miss its opportunities for covenant renewal and atonement. See Shemaryahu Talmon, "What's in a Calendar? Calendar Conformity and Calendar Controversy in Ancient Judaism: The Case of the 'Community of the Renewed Covenant,'” in The Bible and the Dead Sea Scrolls: The Second Princeton Symposium on Judaism and Christian Origins (ed. James H. Charlesworth; Waco: Baylor, 2006), 25-58. 
that characterizes the Gentiles from their very origins following the flood. The second point requires further elaboration.

If one were reading Gen 7-9 one would find a basic sequential structure of flood chronology, then permission to eat meat minus the blood and bloodshed, then the covenant not to flood the earth again. We have already seen how Jubilees combines the qualified permission to eat meat and the covenant not to flood the earth again into a covenantal prohibition of eating blood. The additional point here is that Jubilees also reads the flood chronology as the foundation of a festival calendar and the covenant as a precedent for an annual covenant renewal. The proper calendar is then identified with the proper handling of blood as a fundamental mark of God's people, the Israelites. The rejection of the proper calendar and handling of blood characterizes the Gentiles. Jubilees makes the identification by weaving together and interchanging the Gentile offenses of bloodshed, eating blood, and the calendar. This is true throughout Jub. 6-7, while two passages in particular illustrate the point. First, eating blood is brought as a summary to an extended passage about the calendar, juxtaposing and identifying the errors as inseparable.

For this reason I am commanding you and testifying to you so that you may testify to them because after your death your children will disturb (it) so that they do not make the year (consist of) 364 days only. Therefore, they will err regarding the first of the month, the season, the Sabbath, and the festivals. They will eat all the blood with all (kinds of) meat. (Jub. 6:38)

The errors have no logical relationship of causality, but for Jubilees they are linked in that they both originate in the events surrounding the flood and are both fundamental to the covenant God makes with Noah and his sons. ${ }^{49}$ Jubilees finds the date of the covenant to be part of the covenant, since it is really a covenant renewal and the date for the covenant renewal has long since been fixed in heaven.

This entire festival had been celebrated in heaven from the time of creation until the lifetime of Noah-for 26 jubilees and five weeks of years $[=1309]$. Then Noah and his sons kept it for seven jubilees and one week of years until Noah's death [=350 years]. From the day of Noah's death

49 Segal, The Book of Jubilees, 302-3, makes a different case for a similar point, that the proper calendar is embedded in the covenant between God and Noah. 
his sons corrupted (it) until Abraham's lifetime and were eating blood. (Jub. 6:18)

All nations, since they are descended from Noah, are obliged to the proper calendar including the festival of oaths. Yet as soon as the generation of universal humanity ends and the generations of national division begin, even the same day if the idiom is taken literally, the Gentiles go their wicked way of rejecting the heavenly festival calendar and eating blood. Following the "festivals of the nations" becomes synonymous with forgetting the "covenantal festivals" (Jub. 6:35). Jubilees correlates error in this regard with the system of Gentile error following Noah's death. This etiology of Gentile error is resolved by Abraham's paradigmatic separation and return to the proper calendar and way of eating meat.

While eating blood was an abstract accusation against Gentiles for which they first-and-foremost deserved the terrible fate they had coming to them, the festival calendar was more of an immediate practical concern. By linking the two, Jubilees amplifies the overall case. While the festival calendar had more tangible ramifications, the cause suffered from a relative lack of clear support in received authorities. The issue of "eating blood," however, was already linked to the days of Noah and strong penalties. While the audience may well have thought that the Pentateuch was open to interpretation and flexibility as to the calculation of a month and the festival of weeks in particular, the audience certainly knew that eating blood and idolatry were bad. By including the calendar in the system of Gentile sin, Jubilees implies that using a Gentile calendar is every bit as bad as idolatry and intermarriage. For Jubilees, the harsh rhetoric about Gentile sin and punishment supports a practical point about social separation from Gentiles, beyond intermarriage and idolatry to food, calendar, and shared space.

\section{Conclusion}

Issues of separation from and judgment of Gentiles were frequently discussed in the middle of the second century B.C.E. Jubilees is distinctive in its position and in its argument. Jubilees takes a radical position of absolute separation on every level, certainly including their deeds but also their calendar and even their proximity. Despite the novelty of this position, Jubilees is determined to show that this position is strongly supported by a proper reading of the received authorities. On the one hand, the interpretations in Jubilees should be recognized as deviating from a straight-forward understanding of the texts of 
Genesis, Leviticus, Deuteronomy, and Aramaic Levi. On the other hand, Jubilees works very closely with the sources and avoids bold leaps of logic or rewriting. Jubilees does not simply assert that Israelites should avoid the deeds, diet, and domains of Gentiles, it argues that Gentiles have no future, and any perceived benefit of association will be short-lived. Jubilees does not simply assert that some or all Gentiles will be condemned by God, it argues that the judgment has been recorded in ancient books and is intrinsically binding on all Gentiles. The ancestors of all nations made oaths to a covenant that provides for the eradication of the nations descended from them. There is no possible concern of injustice in their catastrophic fate. The situation leaves no room for repentance, negotiation, or compromise. The avoidance of Gentile idolatry and calendar remain important, but Jubilees further maintains categorically that all Gentile deeds are abhorrent and all of them are doomed.Jubilees persistently maintains an exhortation of separation from Gentiles, but the core of the argument is based on taking a relatively obscure Israelite regulation for butchering meat and building it into a cardinal sin that distinguishes Israel and condemns all Gentiles. 